\title{
ARTICLE \\ Geographic Models of Socioeconomic and Cognitive Development: A Test in Peru
}

\section{Federico R. León *}

Universidad San Ignacio de Loyola, Peru

\begin{tabular}{|c|c|}
\hline ARTICLE INFO & ABSTRACT \\
\hline Article history & \multirow{10}{*}{$\begin{array}{l}\text { Few explanations of geography's influence on economic and cognitive } \\
\text { development have been proposed. This study was purported to test three } \\
\text { development models based on absolute latitude (AL) and additionally } \\
\text { addressed altitude above sea level and the particular case of the Amazonia } \\
\text { in Peru. Information on } 1468 \text { Peruvian districts was obtained from Peru's } \\
\text { Ministry of Education and United Nations Development Program's Human } \\
\text { Development Report. The data were best fitted by ad hoc path models } \\
\text { which combined AL with altitude and took different forms in the Amazonia } \\
\text { and remainder of Peru. AL + altitude explained education + health, and in- } \\
\text { come, through cognitive ability in the Amazonía. In the remainder of Peru, } \\
\mathrm{AL}-\text { altitude explained income and cognitive ability through education } \\
+ \text { health, with an additional, weak but significant, direct AL } \rightarrow \text { cognitive } \\
\text { ability path. The findings add to evidence suggesting the mediation of UV } \\
\text { radiation in the relationship between latitude and development. }\end{array}$} \\
\hline Received: 25 October 2019 & \\
\hline Accepted: 6 November 2019 & \\
\hline Published Online: 30 November 2019 & \\
\hline Keywords: & \\
\hline Absolute latitude & \\
\hline Altitude & \\
\hline Socioeconomic development & \\
\hline Cognitive development & \\
\hline Peru & \\
\hline
\end{tabular}

\section{Introduction}

$\mathrm{T}$ This introduction provides the theoretical context and empirical background of the research presented in the article. A critical summary of geographic, institutional, and genetic explanations for differences observed in nations' wealth is followed by a presentation of evidence on absolute latitude's influence on cognitive ability and wealth and the likely mediating role of UV radiation. Then, study objectives in reference to the specific case of Peru are delineated incorporating altitude as a likely co-determinant and differentiating the Amazonía from the remainder of Peru. The terms intelligence, IQ, cognitive ability, and math and reading scores are used interchangeably based on Rindermann's ${ }^{[80]}$ demonstration that IQ scores and scores from standardized student evalu- ations measure the same construct between nations.

\subsection{Geographic, Institutional, and Genetic Expla- nations of Country Development}

The negative consequences of tropical climate for nations' wealth were insightfully addressed by Kamarck ${ }^{[33]}$. His reasoning suggested that "the adverse effect of tropics arises largely from (a) erratic patterns of tropical rainfall that can play havoc with agriculture; (b) continuous heat and absence of frost that lead to a large variety of weeds, insects, fungi, and other microbes that affect both crops and human life; (c) the consequent abundance of various types of enemies of agriculture; (d) tremendous human health hazards and the associated low productivity, and depressed rates of human and nonhuman capital accumulation; (e) poor quality of tropical soils; and (f) difficulty of finding

*Corresponding Author:

Federico R. León,

Universidad San Ignacio de Loyola, Peru;

Email:federicorleone@gmail.com 
natural resources" ${ }^{[79]}$. The relationship between geography and wealth became more precise when economists started using absolute latitude (AL) ${ }^{[36]}$, i.e., distance from the equatorial line, in their research. Ram ${ }^{[78,79]}$ and Sala-i Martin ${ }^{[87]}$ demonstrated between countries and/or within the United States that income increases with distance from the equator and other studies upheld this relationship using diverse economic indicators ${ }^{[7,13,22,23,65,67,70,72,90]}$. Important empirical confirmations of Kamarck's ideas emerged in the late 1990s and early 2000s and the effects of tropical climate on disease environment and of the latter on economic development appeared to have been well established ${ }^{[5,8,12,24,88,89]}$.

In parallel, however, history had become an alternative source of explanations and finally displaced geography in research on economic development ${ }^{[71]}$. Hall and Jones ${ }^{[30]}$, utilizing instrumental variables, showed that between-country variation in worker productivity was explained by the dissemination of such institutions as rule of law and economic freedom from Western Europe. More to the point, Acemoglu, Johnson, and Robinson ${ }^{[1]}$ argued that the latitude-wealth relationship was spurious. According to their influential paper, the differences in wealth among developing countries started in colonial times. "Europeans adopted very different colonization policies in different colonies, with different associated institutions. The choice of colonization strategy was, at least in part, determined by whether Europeans could settle in the colony. In places where Europeans faced high mortality rates, they could not settle and they were more likely to set up worst (extractive) institutions. These early institutions persisted to the present" ${ }^{[1]}$. These researchers reported that African countries did not present lower incomes nor $\mathrm{AL}$ predicted wealth if the effects of rule of law and other economic and political institutions were controlled. Jeffrey Sachs judged Acemoglu et al's instrumental-variable estimates to be biased ${ }^{[71]}$ and showed that the prevalence of malaria predicted wealth regardless of institutions ${ }^{[88]}$, but most of the published economic-development research aligned with the historicist view ${ }^{[1,18,18,71,72,77,85]}$.

León ${ }^{[42]}$ criticized the lack of parsimony of the historicist explanations of nations' wealth using as example the fact that "free-city formation in Northern Italy in the Middle Ages ${ }^{[29]}$ or ancient immigration from Northern Africa ${ }^{[58]}$, regarded as causes of the current latitudinal gradient of wealth observed in Italy, cannot explain the (dependence of wealth on AL) seen in Brazil ${ }^{[76]}$, China ${ }^{[15]}$, the United States ${ }^{[79]}$, or Western Europe as a whole." Research interest in the economic effects of temperature has been revived and has produced evidence that mean temperature and deviations from the biological optimum have economic consequences
${ }^{[10,17,31]}$. Furthermore, Andersen, Dalgaard, and Selaya ${ }^{[2]}$ showed across 147 countries that absolute latitude and UV radiation explain country wealth. León ${ }^{[47]}$, considering that an overwhelming majority of the 66 ex colonies used as units of analysis in the Acemoglu et al. study were located close to the equator, constructively replicated their research using a more heterogeneous group of countries that included nations closer to the poles which were not colonies at least since $1500 \mathrm{AD}$. Analyzing data from 96 countries, León ${ }^{[47]}$ demonstrated that rule of law, government effectiveness, and economic freedom behave as net dependent variables of UV radiation, both directly and through country wealth. It is surprising that more than 15 years had to elapse until the erroneous conclusions of Acemoglu et al. ${ }^{[1]}$ were so clearly contradicted by the evidence.

On the other hand, evolutionary psychologists addressed the topic with a singular view of country development. Inherited intelligence, not geography, would be the direct source of nations' wealth ${ }^{[61,62]}$. According to Lynn ${ }^{[56]}$, the dark-skinned H. sapiens who stayed in the tropics (e.g., Sub-Saharan Africans) or returned to the tropics after a stay of some millennia at high latitudes (e.g., Peruvians) did not face the opportunities for cognitive growth that the predictable harsh winters of temperate regions afforded to the cousins who established in Europe and Northeast Asia about 40,000 years ago, remained there, and became light-skinned. Such winters would have exerted cognitive demands for survival that resulted in the millenary evolvement of higher levels of intelligence; in this view, the less intelligent humans, unable to anticipate the need for securing warming clothes, adequate food, and safe refuge for the septentrional winter, died early and did not pass their genes into the future; consequently, the average IQ increased. The cognitive capitalism perspective assumes that, presently, cognitive ability determines wealth through the mediation of technology and institutions and disregards contemporary geography as a possible cause ${ }^{[81-}$ ${ }^{83]}$. This view was also challenged in León's ${ }^{[49]}$ study; using structural equation modeling (SEM), he showed that, when the effects of $\mathrm{AL}$ and education and health are taken into account, IQ becomes unrelated to wealth and wealth determines institutions rather than the other way around.

\subsection{The Possible Role of UV Radiation}

Cognitive ability declines with proximity to the equator between countries ${ }^{[33,63]}$ and within such countries as Italy ${ }^{[58]}$, Japan ${ }^{[35]}$, Peru ${ }^{[4,51]}$, Russia ${ }^{[28]}$, Spain ${ }^{[59]}$, Sudan ${ }^{[3]}$, the United States ${ }^{[20,45,46,74,86]}$, and Vietnam (Kirkegaard \& Pesta, 2018), although not in Turkey ${ }^{[60]}$ nor India ${ }^{[64]}$. The exceptions may be accounted for by the greater longitudinal than latitudinal extension of Turkey and the fact that Mus- 
lims, whose IQ is lower than the IQ of followers of other faiths ${ }^{[57,92]}$, are more concentrated in the northern regions of India (Basant \& Shariff, 2010). León ${ }^{[48]}$ has explained why the AL-wealth and AL-IQ relationships may not hold above $52^{\circ} \mathrm{N}$ or $\mathrm{S}$ and prior to the $20^{\text {th }}$ century.

Lynn ${ }^{[58]}$ attributed the latitude-IQ correlation observed in Italy to Middle European versus Mediterranean genes, but was refuted ${ }^{[4,49]}$. Rindermann, Woodley, and Stratford ${ }^{[84]}$ analyzed haplogroups across Europe, but the latitude-IQ $r$ transcends genetic distance from South Africa ${ }^{[53]}$. Even more damaging to the geneticist and cognitive capitalism views is the fact that neither evolutionary nor institutional concepts are able to account for the consistent AL-cognitive ability $r$ found in the megathermal $\mathrm{Am}$ azonía of Peru ${ }^{[51]}$. On the other hand, UV radiation can explain the specific phenomenon on the basis of its strong negative correlation with AL.

UV radiation emerged as a possible encompassing determinant of human behavior when León ${ }^{[4]]}$ appealed to this variable to account for the north-south gradients of married ${ }^{[37]}$ and unmarried women's fertility desire ${ }^{[37]}$ visà-vis women's domestic power ${ }^{[40]}$ observed in Peru. Since UV photons increase production of vitamin $\mathrm{D}^{[34]}$ and this, in turn, increases production of sexual hormones ${ }^{[32]}$, men would be more masculine and women more feminine closer to the equator; this would explain why women are more comfortable with the dependent roles of wife and mother in northern Peru and exhibit greater domestic power in southern Peru. The greater consumption of tobacco, alcohol, and coca leaf in southern than northern Peru ${ }^{[39]}$ was explained by León ${ }^{[43]}$ taking into account that vitamin D also increases production of dopamine, "the neurotransmitter of happiness". He predicted and confirmed empirically a similar gradient of domestic violence; the more positive emotions of northern Peruvians would limit the emergence of domestic violence closer to the equator. Increased dopamine would also affect cognitive growth by inducing play rather than study ${ }^{[51]}$. Having established, against conventional economic wisdom, that southern Peruvians have greater household assets and education levels than northern Peruvians, León ${ }^{[42]}$ considered Lynn and Vanhanen's ${ }^{[61,62]}$ notion that wealth is determined by intelligence. He theorized that the discovered AL-wealth relationship in Peru could be explained by negative effects of UV radiation on cognitive ability considering that larger families (promoted by greater sexual activity under intense UV radiation) are associated with children's diminished access to adult minds ${ }^{[94]}$, decreased educational opportunities ${ }^{[9]}$, and consequent lower IQ ${ }^{[6]}$. In an analysis of 24 Peruvian regions, León ${ }^{[44]}$ showed that birth rate mediated the increasing reading comprehension and math achievements of children in $2^{\text {nd }}$ grade of primary instruction from north to south and then León and Burga León ${ }^{[51]}$, in a more thorough study of standardized student evaluation scores which encompassed 1479 districts, confirmed the trend. The heuristic power of the emerging theory was shown when León ${ }^{[45]}$, considering UV radiation patterns, predicted and confirmed greater math and reading scores in the eastern than western United States.

But there is an alternative hypothesis for the AL-IQ correlation which considers infectious diseases, more frequent closer to the equator. Eppig et al. ${ }^{[21]}$ assumed that the human immunological system needs energy to fight infections and, when these occur in childhood, the system takes energy from the developing brain, thus impairing cognitive growth; these researchers supplied confirmatory data from the United States. However, León ${ }^{[46]}$, in the same country, showed that the effects of AL on math and reading scores transcend the effects of infectious diseases and León and Hassall ${ }^{[55]}$, using direct measurements of UV radiation, demonstrated that the effects of the UV Index on the cognitive ability of White children transcend the effects of both infectious diseases and temperature. Moreover, in the latter study, the AL-cognitive ability $r$ was absent among African American and Hispanic children, plausibly because their high levels of skin melanin absorb and dissipate light.

Yet, some recent findings present contradictions. León and Burga-León ${ }^{[49]}$, using SEMs, found satisfactory model adjustment for a UV Index $\rightarrow$ cognitive ability $\rightarrow$ income linkage (see American Model in Figure 1) but not for a UV Index $\rightarrow$ income $\rightarrow$ cognitive ability linkage in a study of the 48 contiguous states of the United States. This evidence was understood considering that the generation of wealth requires able individuals capable of developing science and technology, designing and implementing innovations in economic life, and effectively managing production and service units. On the other hand, a study of 21 regions and provinces of Italy which addressed a socioeconomic latent variable defined by per capita GDP, education, and unemployment revealed a solar radiation $\rightarrow$ socioeconomic factor $\rightarrow$ cognitive ability SEM (Italian Model of Figure 1) with positive indicators of model adjustment that were absent in the case of a solar radiation $\rightarrow$ cognitive ability $\rightarrow$ socioeconomic factor SEM ${ }^{[49]}$. The results were understood considering that $\mathrm{UV}$ radiation causes cell oxidative stress ${ }^{[68]}$, which has been associated with the presence of fatigue in humans ${ }^{[93]}$; the interpretive hypothesis that explained the findings was that repeated exposure to high UV radiation impairs industriousness, a component of conscientiousness, one of the Big Five personality factors ${ }^{[16]}$. If southern Italians are less industrious, it is only logical that they are also poorer. As for the second leg of the linkage, psychological 
research has shown a strong influence of parents' socioeconomic status on children's IQ ${ }^{[69]}$ and that poverty itself reduces cognitive capacity because poverty-related concerns consume mental resources, leaving less for other tasks ${ }^{[66]}$. The difference observed with respect to the American findings suggested that social mobility based on ability prevails in the United States whereas a more rigid social structure prevails in Italy. Finally, a study of 96 countries yielded the World model of Figure 1. In that study, the SEM that best fitted the structure of the data posited education and life expectancy as mediators of the effects of AL on country income, on one hand, and cognitive ability, on the other ${ }^{[47]}$. Institutional strength emerged as a net dependent variable.

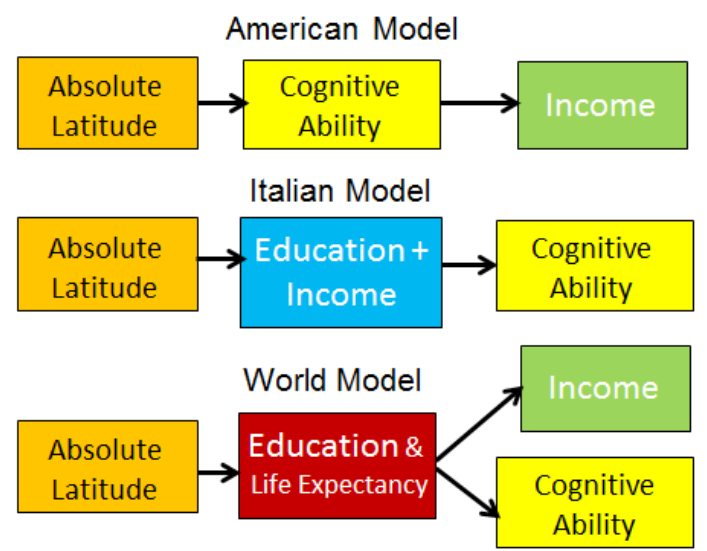

Figure 1. Three geographic models of country development

\subsection{Research Questions}

Foreign Models. Which of the three geographic models of national development does best describe the situation of Peru? Answers to this question were needed on two grounds. First, there was an interest in generating evidence with the potential to clarify the theoretical issue, that is, determine the circumstances leading to the prevalence of one model vis-à-vis another. Second, the findings could help Peruvians to better understand the processes of national development of their country.
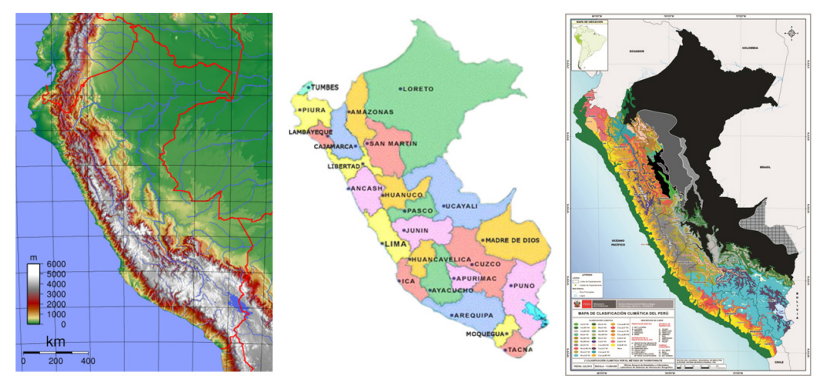

Figure 2. Topographic (left), political (center), and climatological (right) maps of Peru 
the American, Italian, and World models of cognitive and socioeconomic development.

\section{Method}

The study used a data set in the public domain created by León and Burga León ${ }^{[52]}$.

\subsection{Subjects}

The data set has at its nucleus the 2011 national census of children in $2^{\text {nd }}$ grade of primary instruction of the Ministry of Education of Peru $(\mathrm{N}=506,345)$. The students were part of schools, the schools were in some cases part of towns, and the towns were part of districts. The units of observation and analysis for the present study were the 1468 districts which satisfied the Ministry's sampling standards (at least $90 \%$ of schools accessed and $80 \%$ of students tested) and had average data on all the study variables.

\subsection{Measurements}

Cognitive Data. The children responded to questions entailing mathematics and reading comprehension. The reliabilities of the summed scores were $\alpha=.89$ and $\alpha=.87$, respectively. Math and reading correlated 89 .

AL and Altitude. The AL and altitude of the town with the greatest student population within a district were assigned to the district. The measurements were obtained from the website of the Ministry of Education.

Socioeconomic Variables. Three indicators from the Peru 2009 Human Development Report ${ }^{[75]}$ were used. Per capita family income actually refers to expenses in national currency. Educational achievement is an average of literacy and school attendance by the population between 5 and 18 years of age. Life expectancy was calculated considering infant mortality rates.

\subsection{Analytic Strategy}

Data were analyzed separately in the Amazonia and the remainder of Peru. The Amazonía ranges from 1 up to 600 meters above sea level and comprises four humid-megathermal climates represented by the rightmost areas of the climatological map in Figure 2. Owing to difficulties for agriculture, this region is under-populated, over-urbanized, and poorly connected with the rest of the country. $\mathrm{AL}$ and altitude standardized scores were combined as follows:

$(\mathrm{zAL}+\mathrm{zAltitude}) / 2$

zAL - zAltitude
Equation 1 was designed for use with Amazonía data and Equation 2 for use with the remainder of Peru. Path analyses with bootstrapping were used in testing the models. The adjustment criteria for the models were the conventional $\chi 2 / \mathrm{df}<2$ or 3 , SRMR $<.08$, CFI $>.95$, and RMSEA $<.08^{[91]}$.

\section{Results}

Table 1 presents descriptive statistics for the Amazonía and Remainder of Peru. Compared to the latter, the Amazonia is closer to the equator; lower in altitude, cognitive ability, and life expectancy; higher in income and education; and more homogeneous in all the variables. Table 2 shows the inter-correlations between the study variables within each

Table 1. Characteristics of the Amazonía and Remainder of Peru

\begin{tabular}{|c|c|c|c|c|}
\hline Variable & \multicolumn{2}{|c|}{ Amazonía } & \multicolumn{2}{c|}{ Remainder of Peru } \\
\hline & Mean & SD & Mean & SD \\
\hline & 7.39 & 2.56 & 11.29 & 3.43 \\
Absolute latitude & 271 & 143 & 2386 & 1410 \\
Altitude & 471.92 & 41.07 & 507.20 & 45.24 \\
Reading score & 457.97 & 46.24 & 503.34 & 52.36 \\
Math score & 5.40 & 0.32 & 5.34 & 0.44 \\
Log Income & 86.51 & 5.55 & 86.00 & 6.83 \\
Education rate & 71.35 & 1.90 & 71.71 & 2.51 \\
Life expectancy & \multicolumn{2}{|c|}{$(119)$} & \multicolumn{2}{c}{ (1349) } \\
\hline (N) & \multicolumn{3}{|c}{} \\
\hline
\end{tabular}

Table 2. Inter-correlations between study variables, per setting. Amazonía above the diagonal; Remainder of Peru below the diagonal

\begin{tabular}{|c|c|c|c|c|c|c|c|}
\hline Variables & $\mathbf{1}$ & $\mathbf{2}$ & $\mathbf{3}$ & $\mathbf{4}$ & $\mathbf{5}$ & $\mathbf{6}$ & $\mathbf{7}$ \\
\hline $\begin{array}{c}\text { 1. Absolute } \\
\text { latitude }\end{array}$ & - & $.41 * * *$ & $.39 * * *$ & $.40^{* * *}$ & $.28 * *$ & .04 & .15 \\
\hline 2. Altitude & $.36 * * *$ & - & $.42 * * *$ & $.48 * * *$ & .10 & $-.28^{*}$ & $.28 * *$ \\
\hline $\begin{array}{c}\text { 3. Reading } \\
\text { score }\end{array}$ & .03 & $-.46^{* * *}$ & - & $.93 * * *$ & $.57 * * *$ & $.34 * * *$ & $.60 * * *$ \\
\hline $\begin{array}{c}\text { 4. Math } \\
\text { score }\end{array}$ & -.02 & $-.36 * * *$ & $.89 * * *$ & - & $.48^{* * * *}$ & $.25 * *$ & $.54 * * *$ \\
\hline $\begin{array}{c}\text { 5. Log } \\
\text { Income }\end{array}$ & -.03 & $-.61 * * *$ & $.68 * * *$ & $.49 * * *$ & - & $.60^{* * *}$ & $.37 * * *$ \\
\hline $\begin{array}{c}\text { 6. Educa- } \\
\text { tion rate }\end{array}$ & $.12 * * *$ & $-.40^{* * *}$ & $.61 * * *$ & $.44 * * *$ & $.71 * * *$ & - & $.25 * *$ \\
\hline $\begin{array}{c}\text { 7. Life } \\
\text { expectancy }\end{array}$ & $-.12 * * *$ & $-.62 * * *$ & $.48^{* * *}$ & $.36 * * *$ & $.64 * * *$ & $.47 * * *$ & - \\
\hline
\end{tabular}

Note: $* \mathrm{p}<.05, * * \mathrm{p}<.01, * * * \mathrm{p}<.001$.

Setting: The variables are significantly inter-correlated in the Amazonia, with the exception of $\mathrm{AL}$ with education and life expectancy and altitude with income. They are also highly inter-correlated in Remainder of Peru, excepting $\mathrm{AL}$ with income and cognitive abilities. 


\subsection{Foreign Models}

The first study question had to do with the validity of the American, Italian, and world development models in Peru. It can be seen in Figure 3 that only the American

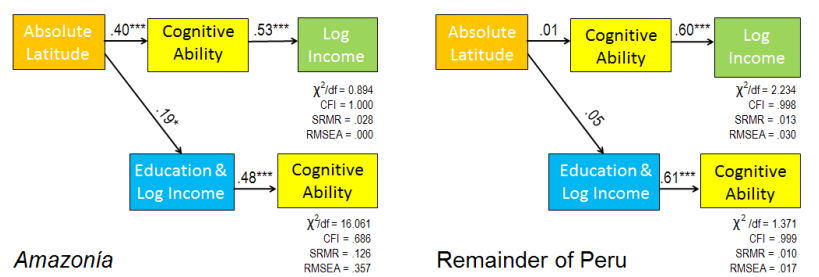

Figure 3. Path coefficients connecting absolute latitude with per capita income through complex cognitive ability (American Model) and with cognitive ability through education + per capita income (Italian Model) in Peru, per setting

Note: Each panel presents two sets of model adjustment indicators, one for model. Significance levels like in Table 2.

Model replicated well in the Amazonia; cognitive ability is an average of math and reading standardized scores. The Italian Model presented satisfactory adjustment criteria in remainder of Peru, but the effects of AL on education and income were not significant. Results for the World Model are shown in Figure 4; this model did not work well in either setting. Evidently, a developmental model oblivious to altitude is destined to failure in Peru, except in a region with low altitudes such as the $A m a-$ zonía.

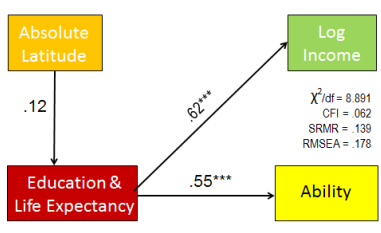

Amazonía

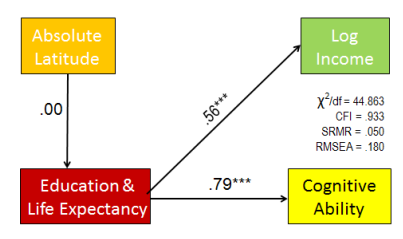

Remainder of Peru
Figure 4. Path coefficients connecting absolute latitude with cognitive ability and per capita income through education + life expectancy (World Model) in Peru, per setting

Note: Significance levels like in Table 2.

\subsection{Combinations of Absolute Latitude and Alti- tude}

Figure 5A depicts the regression of cognitive ability scores on AL having administrative regions as units of analysis. The regression is clearly positive in the case of Peru as a whole, the coastal administrative regions (circles), and the Amazonia (rhombuses), but not in the heterogeneous remainder of the country (rectangles). In the case of the regression of cognitive ability on altitude
(Figure 5B), the sign is negative for Peru as a whole, the coastal administrative regions, and the remainder of the country, but is positive for the Amazonia. The regression of cognitive ability on Equation 2 (Figure 6A) was steeper than that on absolute latitude alone; among other changes, Metropolitan Lima and Callao moved closer to the regression line. An even steeper regression line was obtained when altitude was weighted double than absolute latitude and the Amazonia was treated with Equation 3 and the remainder of Peru with Equation 4 (Figure 6B).

$(0.5 \mathrm{zAL}+\mathrm{zAltitude}) / 2$

$0.5 \mathrm{zAL}-$ zAltitude
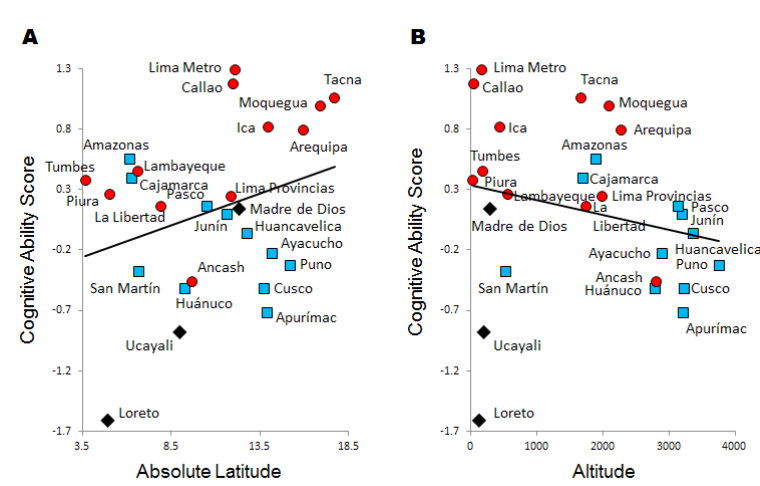

Figure 5. Regression of averaged math and reading standardized scores of 26 administrative regions of Peru on absolute latitude (Panel A) and altitude (Panel B)
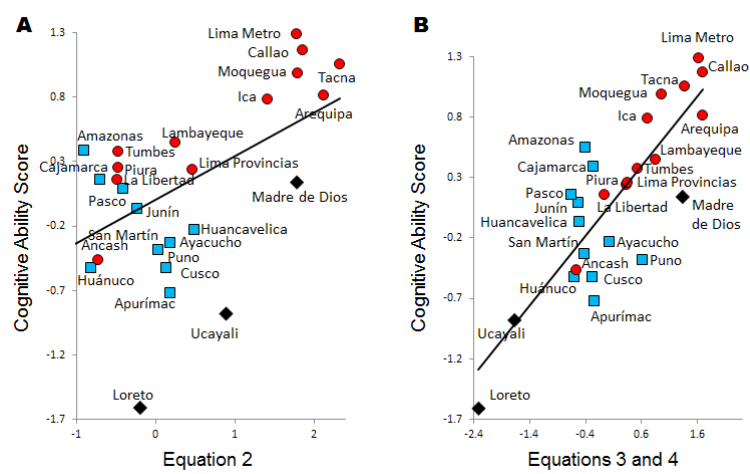

Figure 6. Regression of averaged math and reading standardized scores of 26 administrative regions of Peru on Equation 2 (Panel A) and on Equation 3 for Loreto, Madre de Dios and Ucayali and Equation 4 for the other 22 regions (Panel B)

\subsection{Peruvian Models of Development}

Several ad hoc models were tried using equations 3 ( $\mathrm{Am}$ azonía) and 4 (Remainder of Peru). The upper panels of Figure 7 depict the most successful models. Since the 
model for Remainder of Peru did not meet the model adjustment standards, equations 1 (Amazonía) and 2 (Remainder of Peru) were tried (see lower panels of Figure 7). Whereas the results for the Amazonía changed little, those for Remainder of Peru achieved more satisfactory levels of adjustment. Entering separately education and life expectancy in the equations deteriorated adjustment of the statistical model (not shown).

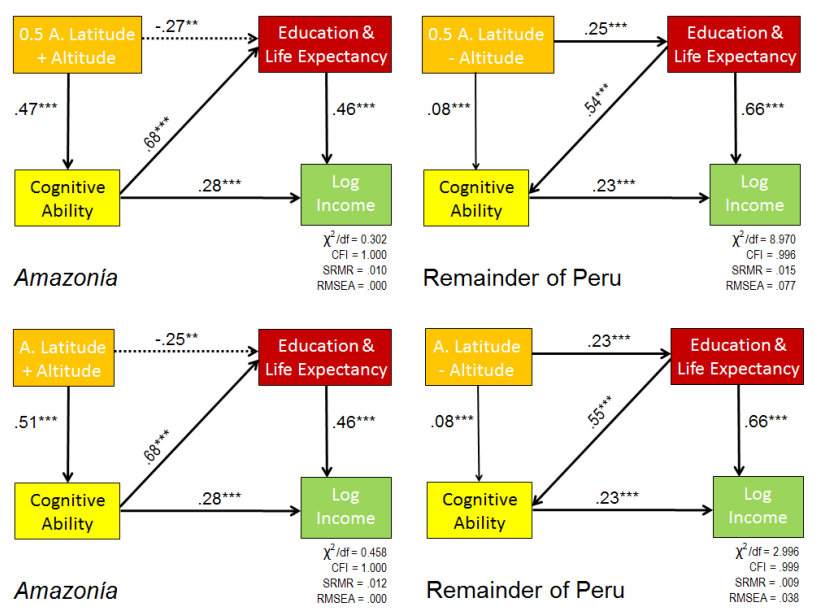

Figure 7. Path coefficients connecting absolute latitude and altitude with complex cognitive ability, per capita income, and education + life expectancy (Ad Hoc Models) in Peru, per setting

Note: In the upper panels, absolute latitude is weighted 0.5 ; in the panels below, it is not. Significance levels like in Table 2.

\section{Discussion}

Different models explain development in the Peruvian habitats addressed. The American Model explained the case of the Amazonia: reading and math abilities were affected by AL in this habitat and, in turn, affected wealth. León and Burga León ${ }^{[51]}$ noted that:

"(In the Amazonia), birth rate's effects on (cognitive ability) were greater than those seen in the other Peruvian regions..., which suggests that the negative cognitive effects of family size are intensified under strong $U V_{B}$ radiation. The Amazonia is the Peruvian region closest to the equator and, given its high temperature, its residents wear slight clothing and expose large parts of the body to sunlight all year round. Regional stereotyping of Amazonians in Peru, pointing to sexual hyperactivity and promiscuity, suggests deficits of parenting, which could help explain an incongruous finding of the study: whereas the Amazonia occupied an intermediate position between the rich coast and poor remainder of the country in social development, it fell behind the latter in (cognitive ability)... Consistent with the emerging explanatory hypothesis on parenting, the effects of birth rate on (cognitive ability) decayed from northern to central to southern latitudinal segments when we divided the Amazonía into three equal parts."

The American Model specifies positive effects of AL on cognitive ability and implies high social mobility based on personal ability. Sociological studies comparing the social mobility of the Amazonia with the remainder of Peru are needed to confirm this interpretive hypothesis.

A comparison of Figure 3 with Figure 7 shows that the path coefficients and indicators of model adjustment in the Amazonía improved when the American model was combined with altitude and incorporated education and health. Since infectious diseases decrease with altitude in the Amazonia, the improvement of the statistical model can be interpreted along Eppig et al.'s (2009) conception that child infections interfere with cognitive development. That is, the negative cognitive effects of infectious diseases in childhood would add to the impairment of cognitive ability caused by the larger families and deterioration of parenting under greater exposure to UV radiation. On the other hand, the Peruvian development models designed for the Amazonia (upper and lower leftmost panels of Figure 7) presented a negative relationship between $\mathrm{AL}+$ altitude and education + life expectancy. This may reflect the concentration of more and better educational and health services in the larger cities of the northern than southern Amazonía (Iquitos/Loreto, pop. 437376; Pucallpa/Ucayali, pop. 211651; Puerto Maldonado/Madre de Dios, pop. 74494). More generally, the Amazonian findings help to understand the poor GDPs of Sub-Saharan African countries, exposed to strong UV radiation and high rates of infectious diseases and, consequently, characterized by very low IQs ${ }^{[63]}$. They also suggest straightforward remedies both for the Amazonia and Sub-Saharan Africa: reduced exposure to UV radiation, more effective use of contraceptive methods, and control of infectious diseases. This should immediately improve the cognitive growth of children. It can be expected that, as adults, they will become richer and, as authorities, contribute to the improvement of education and health.

The American Model failed to explain the situation of Remainder of Peru and both the Italian and World models failed in both habitats (Amazonía and Remainder of Peru). However, inclusion of altitude with inverted sign and equal weight as AL in the World Model yielded a statistically satisfactory model in Remainder of Peru (Figure 7). León \& Burga-León ${ }^{[54]}$ interpreted the World Model considering that the effects of absolute latitude on education/ health can be understood considering the possible mediation of the oxidative stress caused by UV radiation:

"The free radicals associated with cell oxidative stress 
have been implicated in the pathology of several human diseases, including cancer, atherosclerosis, malaria, rheumatoid arthritis, and neurodegenerative diseases (Aruoma, 1998). Rate of disease has been shown to impair CCA (Daniele \& Ostumi, 2013)... Disease is also likely to cause desertion from school (and) impoverish educational achievements..."

It seems only logical that people close to the equator are less healthy and less educated. The creation of wealth demands healthy and educated economic agents, and the growth of cognitive ability is impaired by deficits in education ${ }^{[69]}$. Moreover, energetically costly infectious diseases of the child impair cognitive growth.

\section{Conclusions}

An $\mathrm{AL}-$ altitude $\rightarrow$ education + life expectancy $\rightarrow$ wealth and cognitive ability chain of effects explains development among an overwhelming majority of the population of Peru. It should be noted, however, that the impact of $\mathrm{AL}$ - altitude on education + life expectancy in Remainder of Peru was weaker than that of AL + altitude on cognitive ability in the Amazonía. The interpretation proposed here is that the latter entails contemporary effects of $\mathrm{AL}+$ altitude whereas the former involve historical, cumulative effects of AL - altitude. In other words, the effects of geography in the Amazonia would be visible in one generation whereas those in Remainder of Peru would require several generations. Changes in the life expectancy of a population and in the rates of educational achievements take a time to materialize and are probably related to culturally determined ways of life with impacts on health as well as to the educational aspirations of society. The results of the present study highlight the importance of health and education in the causation of wealth and cognitive ability in Peru. On the other hand, AL simultaneously affected cognitive ability directly, though somewhat weakly. This may reflect a contemporary effect.

\section{References}

[1] Acemoglu, D., Johnson, S., \& Robinson, J. A.. The colonial origins of comparative development: An empirical investigation. NBER Working Paper No. 7771, 2000.

[2] Andersen, T.B., Dalgaard, C-J., \& Selaya, P.. Climate and the emergence of global income differences. Review of Economic Studies, 2016, 83: 1334-1363.

[3] Bakhiet, A. F. A., \& Lynn, R.. Regional differences in intelligence in Sudan. Intelligence, 2015, 50: 150152.

[4] Beraldo, S.. Do differences in IQ predict Italian north-south differences in income? A methodological critique to Lynn. Intelligence,2010, 38: 456-461.

[5] Bhattacharyya, S.. Root causes of African underdevelopment. Journal of African Economies, 2009, 18: 745-780.

[6] Bjerkedal, T., Kristensen, P., Skjeret, G. A., \& Brevik, J. I.. Intelligence test scores and birth order among young Norwegian men (conscripts) analyzed within and between families. Intelligence, 2007, 35: 503-514.

[7] Bleaney, M., \& Dimico, A.. Geographical influences on long-run development. Journal of African Economies, 2010, 19: 635-656.

[8] Bloom, D., \& Sachs, J. D.. Geography, demography, and economic growth in Africa. Brookings Papers on Economic Activity, 1998, 2.

[9] Booth, A. L., \& Kee, H. J.. Birth order matters: The effect of family size and birth order on educational attainment. Journal of Population Economics, 2009, 22: 367-397.

[10] Burke, M., Hsiang, S. M., \& Miguel, E.. Global non-linear effect of temperature on economic production. Nature, 2015, 527: 235-239.

[11] Cáceres, C., Mendoza, W., Yon, C., Rosasco, A., \& Cabezudo, C.. SIDA en el Perú: Imágenes de diversidad, situación y perspectivas de la epidemia en Chiclayo, Cuzco e Iquitos. Lima: UPCH y REDES Jóvenes, 1998.

[12] Carstensen, K., \& Gundlach, E.. The primacy of institutions reconsidered: direct income effects of malaria prevalence." The World Bank Economic Review, 2006, 20: 309-339.

[13] Cinyabuguma, M. M., \& Putterman, L.. Sub-Saharan growth surprises: being heterogeneous, inland and close to the Equator doesn't slow growth within Africa. Journal of African Economies, 2011, 20: 217-262.

[14] Comin, D., Easterly, W., \& Gong, E.. Was the wealth of nations determined in 1000 B.C.? Working Paper No. 09-052, Harvard Business School, 2007.

[15] Démurger, S., Sachs, J. D., Woo, W. T., Bao, S., Chang, G., \& Mellinger, A.. Geography, economic policy, and regional development in China. Asian Economic Papers, 2002, 1: 146-197.

[16] DeYoung, C. G., Quilty, L. C, \& Peterson, J. B.. Between facets and domains: 10 aspects of the Big Five. Journal of Personality and Social Psychology, 2007, 93: 880-896.

[17] Dell, M., Jones, B. F., \& Olken, B. A.. Temperature shocks and economic growth: Evidence from the last half century. American Economic Journal: Macroeconomics, 2012, 4(3): 66-75.

[18] Easterly, W., \& Levine, R.. Tropics, germs, and 
crops: how endowments influence economic development. NBER Working Paper 9106, 2002.

[19] ENDES. Encuesta Demográfica y de Salud Familiar 2011. Lima: INEI, 2012.

[20] Engelsen, O., Brustad, M., Aksnes, L., \& Lund, E.. Daily duration of Vitamin D synthesis in human skin with relation to latitude, total ozone, altitude, ground cover, aerosols and cloud thickness." Photochemistry and Photobiology, 2007, 81: 1287-1290.

[21] Eppig, C., Fincher, C. L., \&Thornhill, R.. Parasite prevalence and the distribution of intelligence among the states of the USA. Intelligence, 2011, 39: 155160.

[22] Gallup, J. L.. Geography and socioeconomic development. Background paper examining the state of the Andean Region for the Andean Competitiveness Project, 2000.

http://www.cid.harvard.edu/

[23] Gallup, J. L., Gaviria, A., \& Lora, E.. Is Geography Destiny? Lessons from Latin America. Stanford, CA: Stanford University Press, 2003.

[24] Gallup, J. L., Sachs, J. D., \& Mellinger, A.. Geography and economic development. International Regional Science Review, 1999, 22: 179-232.

[25] Gonzales, G. F., \& Ortíz, I.. Age at menarche at sea level and high altitude in Peruvian women of different ethnic background." American Journal of Human Biology, 1994, 6: 674-640.

[26] Gonzales, G. F., Tapia, V., Gasco, M., \& Gonzales-Castañeda, C.. Serum testosterone levels and source of chronic mountain sickness in Peruvian men natives at $4340 \mathrm{~m}$. Andrologia, 2011, 43: 189-195.

[27] Gonzales, G. F., \& Villena, A.. Age at menopause in central Andean Peruvian women. Menopause, 1997, 4: $32-38$.

[28] Grigoriev, A., Lapteva, E., \& Lynn, R.. Regional differences in intelligence, infant mortality, stature and fertility in European Russia in the late nineteen century. Intelligence, 2016, 55: 34-37.

[29] Guiso, L., Sapienza, P., \& Zingales, L.. Long term persistence. NBER Working Paper No. 14278, 2008.

[30] Hall, R. E., \& Jones, C. I.. Why do some countries produce so much more output per worker than other countries? Quarterly Journal of Economics, 1999, 114: 83-116,

[31] Heal, G., \& Park, J.. Feeling the heat: Temperature, physiology, and the wealth of nations. NBER Working Paper No. 19725, 2013.

[32] Jones, G., Strungnell, S. A., \& DeLuca, H. F.. Current understanding of the molecular actions of vitamin D. Physiology Review, 1998, 78: 1193-1231.

[33] Kamarck, A. M.. The tropics and economic devel- opment. Baltimore, MD: Johns Hopkins University Press, 1976.

[34] Kennedy, G., Spence, V. A., McLaren, M., Hill, A., Underwood, C., \& Belch, J. J. F.. Oxidative stress levels are raised in chronic fatigue syndrome and are associated with clinical symptoms. Free Radical Biology and Medicine, 2005, 39: 584-589.

[35] Kura, K.. Japanese north-south gradient in IQ predicts differences in stature, skin color, income, and homicide rate. Intelligence, 2013, 41: 512-516.

[36] Latitude and longitude of a point, 2016. Retrieved from:

https://itouchmapcom/latlong.html

[37] León, F.R.. El eje fecundatorio norte-sur del Perú: una interpretación psicológica. Revista de Psicología, 1984, 2: 85-111.

[38] León, F. R. ed.. Psicología y realidad peruana: el aporte objetivo. Lima: Mosca Azul Editores, 1986.

[39] León, F. R.. Las drogas y las madres sureñas y norteñas: el eje psicoactivo norte-sur del Perú. Socialismo y Participación, 1987, 37: 123-129.

[40] León, F. R.. Latitud sur y control económico del hogar por la mujer peruana. Revista de Psicología, 2011, 29: 361-388.

[41] León, F. R.. Una teoría psicobiogeográfica del poder doméstico de la mujer. Revista Peruana de Psicología y Trabajo Social, 2012a, 1: 29-43.

[42] León, F. R.. Ajuste de la violencia familiar peruana a la teoría psicobiogeagráfica de la salud mental. Revista de Psicología, 2012b, 30: 341-369.

[43] León, F. R.. The latitudinal tilts of wealth and education in Peru: Testing them, explaining them, and reflecting on them. Economía, 2012c, 35: 60-102.

[44] León, F. R.. Efectos de la latitud en el logro escolar: ¿Evolucionarios o vía la radiación ultravioleta contemporánea? En D. Jáuregui, R. León, \& M. A. Rodríguez (eds.), Homenaje a Reynaldo Alarcón, Lima: Editorial Universitaria URP, 2015a: 473-496..

[45] León, F. R.. The east-to-west decay of math and reading scores in the United States: A prediction from UVB radiation theory. Personality and Individual Differences, 2015b, 86: 287-290.

[46] León, F. R.. Race vis-à-vis latitude: Their influence on infectious diseases, complex cognitive ability, and income per capita. Mankind Quarterly, 2016, 56: 411-419.

[47] León F.R.. Diminished UV radiation enhances national cognitive ability, wealth, and institutions through health and education. Personality and Individual Differences, 2018a, 120: 52-57.

[48] León F.R.. Boundary conditions and new directions for UVR Theory: Reply to comments. Mankind 
Quarterly, 2018b, 58: 621-649.

[49] León, F.R., \& Antonelli-Ponti, M.. UV radiation theory and the Lynn (2010) Italian debate. Mankind Quarterly, 2018, 57: 621-649.

[50] León, F. R., \& Avilés, E.. How altitude above sea level affects Intelligence. Intelligence, 2016, 58: 3341.

[51] León, F. R., \& Burga León, A.. Why complex cognitive ability increases with absolute latitude. Intelligence, 2014a, 46: 291-299.

[52] León, F.R., \& Burga León, A. 2014b, Data base: http://investigacion.usil.pe/ojs/index.php?journal=repAcademic\&page $=$ index

[53] León, F. R., \& Burga-León, A.. How geography influences complex cognitive ability. Intelligence, 2015, 50: 221-227.

[54] León, F.R., \& Burga-León, A.. UV radiation associates with state income through complex cognitive ability in the USA. Journal of Individual Differences, 2018, 39: 18-26.

[55] León, F.R., \& Hassall, C.. UV radiation is associated with latitudinal trends in cognitive ability of White children in the USA. Journal of Individual Differences, 2017, 38: 155-162.

[56] Lynn, R.. The evolution of race differences in intelligence. Mankind Quarterly, 1991, 32: 99-173.

[57] Lynn, R.. The global bell curve: Race, IQ, and inequality worldwide. Augusta: GA: Wahington Summit Publishers, 2008.

[58] Lynn, R.. In Italy, north-south differences in IQ predict differences in income, education, infant mortality, stature, and literacy. Intelligence, 2010, 38: 93100.

[59] Lynn, R.. North-south differences in Spain in IQ, educational attainment, per capita income, literacy, life expectancy and employment. Mankind Quarterly, 2012, 52: 265-291.

[60] Lynn, R., Sakar, C., \& Cheng, H.. Regional differences in intelligence, income and other socioeconomic variables in Turkey. Intelligence, 2015, 50: 144-149.

[61] Lynn, R., \& Vanhanen, T.. IQ and the wealth of nations. Westport, CT: Praeger, 2002.

[62] Lynn, R., \& Vanhanen, T.. IQ and Global Inequality. Athens, GA: Washington Summit Publishers, 2006.

[63] Lynn, R., \& Vanhanen, T.. National IQs: A review of their educational, cognitive, economic, political, demographic, sociological, epidemiological, geographic and climactic correlates. Intelligence, 2012, 40: $226+234$.

[64] Lynn, R., \& Yadav, P.. Differences in cognitive ability, per capita income, infant mortality, fertility and latitude across states of India. Intelligence, 2015, 49:
179-185.

[65] Maccarthur, J. W., \& Sachs, J. D.. Institutions and geography: comment on Acemoglu, Johnson and Robinson (2000). NBER Working Paper No. 8114, 2001.

[66] Mani, A., Mullainathan, S., Shafir, E \& Zhao, J.. Poverty impedes cognitive function. Science, 2013, 341: 976-980.

[67] Masters, W. A., \& Mcmillan, M. S.. Climate and scale in economic growth. The Centre for the Study of African Economies Working Paper Series No. 123, 2000.

[68] Meng, J. Y., Zhang, C. Y., Zhu, F., Wang, X. P., \& Lei, C. L.. Ultraviolet light-induced oxidative stress: effects on antioxidant response of Helicoverpa armigera adults. Journal of Insect Physiology, 2009, 55: 588-592.

[69] Nisbett, R. E., Aronson, J., Blair, C., Dickens, W., Flynn, J., Halpern, D. F., \& Turkheimer, E.. Intelligence: New findings and theoretical developments. American Psychologist, 2012, 67: 130-159.

[70] Nordhaus, W. D., \& Chen, X.. Geography: graphics and economics. The B. E. Journal of Economic Analysis \& Policy, 2009, 2(1).

[71] Nunn, N.. The importance of history for economic development. Annual Review of Economics, 2009, 1: 65-92.

[72] Olsson, O., \& Hibbs Jr., D. A.. Biogeography and long-run economic development. European Economic Review, 2005, 49: 909-938.

[73] Paris, M., Gotuzzo, E., Goyzuetas, G., Aramburú, J., Cáceres, C., Crawford, D., et al.. Motorcycle taxi drivers and sexually transmitted infecions in a Peruvian Amazon city. Sexually Transmitted Diseases, 2001, 28: 11-13.

[74] Pesta, B. J., \& Posnanski, P. J.. Only in America: Cold Winters theory, race, IQ and well-being. Intelligence, 2014, 46: 271-274.

[75] PNUD. Informe de Desarrollo Humano, Perú 2009. Lima: Programa de las Naciones Unidas para el Desarrollo, 2010.

[76] PNUD Brasil. Relatório de Desenvolvimiento Humano: Racismo, Pobreza e Violéncia. Brasilia: Programa das Nacoes Unidas para o Desenvolvimiento, 2005.

[77] Putterman, L., \& Weil, D. N.. Post-1500 population flows and the long-run determinants of economic growth and inequality. The Quarterly Journal of Economics, 2010, 125: 1627-1682.

[78] Ram, R.. Tropics and economic development: An empirical investigation. World Development, 1997, 25: $1443-1452$. 
[79] Ram, R.. Tropics and income: A longitudinal study of the U. S. states. Review of Income and Wealth, 1999, 45: 373-378.

[80] Rindermann, H.. The g-factor of international cognitive ability comparisons: The homogeneity of results in PISA, TIMSS, PIRLS, and IQ-tests across nations. European Journal of Personality, 2007, 21: 667-706.

[81] Rindermann, H.. Intellectual classes, technological progress and economic development: The rise of cognitive capitalism. Personality and Individual Differences, 2012, 53: 108-113.

[82] Rindermann, H., \& Thompson, J.. Cognitive capitalism: The effect of cognitive ability on wealth as mediated through scientific achievement and economic freedom. Psychological Science, 2011, 22: 754-763.

[83] Rindermann, H., Kodila-Tedika, O., \& Christainsen, G.. Cognitive capital, good governance, and the wealth of nations. Intelligence, 2015, 51: 98-108.

[84] Rindermann, H., Woodley, M. A., \& Stratford, J.. Haplogroups as evolutionary markers of cognitive ability. Intelligence, 2012, 40: 362-375.

[85] Rodrik, D., Subramanian, A., \& Trebbi, F.. Institutions rule: the primacy of institutions over geography and integration in economic development. Journal of Economic Growth, 2004, 9: 131-165.

[86] Ryan, J. J., Bartels, J. M., \& Townsend, J. M.. Association between climate and IQ in the United States of America. Psychological Reports, 2010, 107: 251-254

[87] Sala-i Martin, X. X.. I just ran two million regressions. The American Economic Review, 1997, 87:
178-183.

[88] Sachs, J. D.. Institutions don't rule: Direct effects of geography on per capita income. NBER Working Paper No. 4490, 2003.

[89] Sachs, J. D., \& Melaney, P.. The economic and social burden of malaria. Nature, 2002, 415: 680-685.

[90] Sachs, J. D.. Tropical underdevelopment. Center for International Development, Harvard University, Working Paper No. 57, 2000.

[91] Schreiber, J. B., Stage, F. K., King, J., Nora, A., \& Barlow, E. A.. Reporting structural equation modeling and confirmatory factor analysis results: A review. The Journal of Educational Research, 2006, 99: 324-337.

[92] Templer, D. L.. The comparison of mean IQ in Muslim and non-Muslim countries. Mankind Quarterly, L, 2010: 188-209.

[93] Wang, J., Ge, Y., Ning, H., \& Wang, S.. Effects of high fluoride and low iodine on oxidative stress and antioxidant defense of the brain in offspring rats. Fluoride, 2004, 37: 264-270.

[94] Zajonc, R. B., \& Mullally, P. R.. Birth order: Reconciling conflicting effects. American Psychologist, 1997, 52: 685-699.

[95] Zavaleta, C., Fernández, C., Konda, K., Valderrama, Y., Vermund, S. H., \& Gotuzzo, E.. Short report: High prevalence of HIV and syphilis in a remote native community of the Peruvian Amazon. American Journal of Tropical Medicine Hygiene, 2009, 76: 703-705. 